\title{
Effect of Organizational Culture and Managerial Competence on Performance of Lecturerin Obstetrics Study Program at Private University of North Sumatera
}

\author{
Salim Aktar' ${ }^{1}$ Prof. Dr. Zainuddin, M.Pd ${ }^{2}$; Prof. Dr. H. Abdul Muin Sibuea, M.Pd ${ }^{2}$ \\ ${ }^{1}$ (Post Graduate Program, State University of Medan, Indonesia) \\ ${ }^{2}$ (Professor, State University of Medan, Indonesia)
}

\begin{abstract}
This study aims to determine the effect of: (1) organizational culture on performance of lecturer, and (2) managerial competence of lecturer on performance of lecturer. Subjects were lecturers at study program of obstetrics of Private University in North Sumatera, with a total sample of 172 respondents. Tool measuring instruments used in data retrieval organizational culture, managerial competence by using a Likert scale questionnaire. For performance data used direct observation to lecturers of obestetrics program at Private University in North Sumatera. Before the research instrument used in this study, it tested first, followed by validity and reliability testing. To test the validity questionnaire used calculation formula product moment, and to test the reliability of the questionnaire used alpha formula. Coefficientreliability of Organizational culture questionnaire is 0.921 and coefficientreliability of managerial competence is 0.904 . Thus the instruments are the very high category questionnaire. To test the hypothesis proposed in this study used the techniques of correlation and path coefficient. Based on hypothesis tested,it can be concluded that there is a direct and significant effect: (1) organizational culture on performance of lecturer with path coefficient $=0.222$, (2) managerial competence of lecturer on performance of lecturer with path coefficient of 0,156 .
\end{abstract}

Key Words: performance of lecturer, organizational culture, managerial competence of lecturer.

\section{BACKGROUND}

Universities as centers of human resources is expected to produce superior graduates, qualified, with a graduate characterized by cautious, intelligent, creative, professional, and productive. In order to achieve the goals, university can do several indicators of the quality management of universities.

In order to achieve excellence university, qualified and relevant to the needs of the community and national development, there are some strategies that will be implemented by the management of university, namely: (1) improve the quality of education, research and community service through internal quality assurance and external quality assessment system through independent accreditation by the National Acreditation Board of University (BAN-PT), also the acquisition of ISO and accreditation of international institutions; (2) developing a curriculum and instructional quality, effective, and relevant to the needs of students and stakeholders, which produces graduates who are righteous, noble, independent, intelligent and skilled, creative, professional, and productive; (3) increase the number and quality of lecturers and students by facilitating research and community service; (4) improve the quality, competence and qualifications of lecturers.

University is as one of the educational institution that the task is implementation of the Tri Dharma of University, in order to increase competitiveness, performance, productivity, quality, relevance, and effectiveness and efficiency, it is necessary to reform any educational component in it. One vital component that needs to be addressed in order to improve performance, productivity, effectiveness, and efficiency and improving the execution of tasks Tri Dharma of University in providing education, services to students, and society by improving the quality of human resources, especially increasing quality of the lecturers.

Accordance to Wibowo, performance is an implementation of the plans that have been prepared. Implementation of performance carried out by human resources who have the ability, competence, motivation and interest. How the organization respects and treats its human resources will affect the attitudes and behavior in running performance. According to Timpe, performance is the culmination of three interrelated elements, namely: skill, effort, and the nature of external circumstances.

Benardin and Russel defined the performance as the record of out comes produced on a specified job function or activity during as specified time periods". According to Robbin in Rivai performance as a function of the interaction between the ability (A), motivation (M) and opportunity (O), which is performance - $\mathrm{f}(\mathrm{A} \times \mathrm{M}$ $\times \mathrm{O}$ ), it meanthe performance is a function of ability, motivation and opportunity. Opportunity is the highest level of performance. 
Performance model developed by Colquitt et.al. confirms that the overall performance is affected by the four components, namely: Organizational Mechanism, Group Mechanism, Individual Characteristics and Individual Mechanism. Components of organizational mechanisms, included organizational culture and organizational structure, the component of group mechanisms included team processe, team characterstics, leadership style and behavior, and leadership power and influence. Characteristics of individual components consisting of personality and culture values and abilities, while other components are individual mechanism included job satisfaction, stress, motivation, trust, justice and ethics, as well as learning and decision making. While the performance model by Newstrom, the performance is influenced by several variables, namely: organizational culture, leadership, communication, and motivation. Where the variable of organizational culture is influenced by other variables, namely, the formal organization and non-formal organization.

Private university is a university that was founded and/or held by the community. There are 113 programs in consentration of obstetrics at private university in the Province of North Sumatera, with the number of lecturers as many as 906 lecturers, where the total number of lecturers have academic qualifications Strata three $(\mathrm{PhD})$ : 2 lecturers, Strata two (Master):144 lecturers; Specialist: 386 lecturers, Profession:19 lecturers and Diploma two:14 lecturers,

If viewed from the total number of lecturers there, then there should be many results of research in obstetrics, which can be used as an input to people, especially in North Sumatra, when the results of the research devoted to the interests and welfare of society. But in reality the data obtained from Kopertis Region I North Sumatra, as the data of praresearchfound that in 2014, lecturer in obstetrics programwho conduct research only 20 persons, while for the field of community service does not exist, in 2013 and 2012 there was only one person lecturer conducted research, for public service does not exist.

So according to the researchers that the performanc of lecturer in obstetrics programat private university in North Sumatera needs to be studied and analyzed scientifically, what factors that caused the low performace, which studied from effect of organizational culture and managerial competence in their workplace.

\section{LITERATURE REVIEW}

\section{The Performance of Lecturer}

Performance has a broader meaning, not only expressed as a result of the work, but also how the processe work in progress. The performance is about doing the work and results of the work. Performance is about what you do and how to do it. Performance is the result of work that has a strong relationship with the organization with strategic objectives and customer satisfaction.

According to Wibowo: performance is an implementation of the plan has been prepared. Implementation of performance carried out by human resources who have the ability, competence, motivation and interests. "How can the organization appreciates and treats its human resources will affect the attitudes and behavior in running performance.

According to Timpe, the performance was "the culmination of the three elements are interrelated, namely: skill, effort, and the nature of external circumstances." Benardin and Russel defined "performance is as the record of out comes produced on a specified job function or as activity during specified time periods. "

According to Robbin in Rivai, "the performance is as a function of the interaction between the ability $(\mathrm{A})$, motivation $(\mathrm{M})$ and opportunity $(\mathrm{O})$, which is performance - $\mathrm{f}(\mathrm{A} \times \mathrm{M} \times \mathrm{O})$ that is to say, the performance is a function of the ability, motivation and opportunity. And the opportunity is the highest level of performance.

From the definition above, it can be understood that: (1) performance is the willingness of a person or group of people to do the activities/tasks and perfect them in accordance with its responsibilities with the results as expected, (2) the performance is a process in the management of human resources that had implications on the activities carried out a process of general management starts with setting goals and objectives, implementation, direction, and ends with the evaluation, and (3) the performance associated with job satisfaction levels and rates of return has been affected by the skills, abilities and individual properties. Performance related to job satisfaction is a feeling towards work. Feeling as a result of an assessment of how far the work as a whole is able to satisfy the needs.

\section{Organizational Culture}

Cultural organizations will bear the norm as a standard accepted by the members of the organization with certain characteristics or an unwritten rule, among other things: First, the norms established only with respect to things that are important for the organization's members. Second, the norm is accepted in varying degrees by the members of the organization, there is a norm accepted fully, and there is also partially accepted. Therefore, the norm is an agreement that became unwritten rule, but implied and understood by all members of the organization. 
Luthans said that organizational culture has a number of important characteristics, some of which are: (1) The rules of behavior were observed. When members of the organization interact each other, they use language, terms, and public rituals pertaining to respect and how to behave; (2) Norms. There is a standard of behavior, include guidelines on how much work is done, which in many companies become: do not do too much and not too little; (3) Dominant value. Organizational support and hope that the participants share the core values; (4) Philosophy. There are policies that build trust in organizations on how employees and or customers are treated; (5) Rules. There are strict guidelines relating to company's target. Newcomers must learn the techniques and procedures in order to be accepted as a member of a growing group; and (6) Organizational climate. This is an overall feeling conveyed by the physical setting, the way participants interact, and how members of the organization in touch with customers and people from outside.

According to Robins, "organizational culture is a common perception held by members of the organization on a system of shared meaning. From the same source Robins also interpret that organizational culture is a basic philosophy that gives direction to the organization's policy in the management of employees and customers.

While Owen defined organizational culture is as a norm which informs members of the organization about what acceptable is, the dominant values that respected organization over the others, assumptions and beliefs held with members of the organization, rules that must be learned if you want consistent and accepted as members of the organization, philosophy that directs organization in dealing with its employees and subordinates.

\section{Managerial Competence}

Wibowo (2009: 111) argued also "the competence is individual characteristics that underlie work performance or behavior. In line withSpencer and Spencer (1993: 9) stated "A competency is an underlying characteristic of an individual that is causally related to criterion-referenced effective and/or superior performance in a job or situation". It means competence is a fundamental characteristics of the individu, which causes associated with the reference criterion of effective performance".

In connection with Slocum and Hellriegel (2004: 8) stated also "the self competency includes the knowledge, skills and abilities to assess your own strength and weaknesses, set and pursue professional and personal goals: balance work and personal life: and engage in new learning - including new or modified skills, behaviors, and attitudes ". Which means, competence included knowledge, skills and abilities to explore the strengths and weaknesses of yourself, set goals and achieve professionally and continue to learn, to behave and act in terms of new skills.

In Wibowo (2009: 111) Spencer and Spencer explained that there are five characteristics in the competence, namely: 1) The motive is something that consistently thinks or wants the person who caused the action. Motive encourages, directs, and choose the action or behavior towards a particular goal. 2) Physical characteristics and properties are consistent response to a situation or information. Example: The speed of reaction and sharpness of the eyes are the physical characteristics of one's competence fighter pilot. 3) The concept itself is attitudes, values, or the image of a person. Self-confidence is the belief that they can be effective in almost any situation is part of the concept of the person. 4) Knowledge is information that people have in their specific field. Knowledge is a complex competence. Scores on tests of knowledge often fail to predict performance for failing to measure the knowledge and skills in a way that is actually used in the work. 5) Skill is the ability to do certain physical or mental tasks. Competence mental or cognitive skills including analytical and conceptual thinking.

\section{RESEARCH METHODOLOGY}

This research was conducted in Obstetrics Program at private university in North Sumatra Province and the time of the research was May untill December 2015. In this study, the population were all lecturers in Obstetrics Program at private university in North Sumatra, with the criteria the lecturer is permanent lecturer who has a minimum qualification of strata two, and has National Identification Number of Lecturer (NIDN), with a total of 310 lecturers. The sample is part of the number and characteristics possessed by this population. Arikunto (2006: 136) stated that the acquisition of the sample more accurately, It is necessary use formula Issac and Michael, then obtained a sample of 172 lecturers.

The research instrument is a tool that used to collect research data, so the validity and reliability determine the quality of data to be analyzed to obtain the conclusion of a study. To get the research instruments valid and reliable, It is important to develop the instrument in accordance with the theory of measurement, and research instrument is in the form of non test. In connection with it, Djaali and Muljono proposed the steps to develop research instruments, namely: (1) synthesize theories be assessed on a concept of a variable to be measured; (2) based on the construct developed dimensions and indicators of variables to be measured; (3) make 
a grating instrument in the form of a table of specifications that included dimensions, indicators, item number and the number of items for each dimension and indicators; (4) determine the amount or parameter which is engaged in a range of the continuum; and (5) write instruments grains that can form a statement or question.

Therefore, all the research instrument used to collect the data variables in this study developed through the stages icluded: conducting the study of theory about the concept of the study's variable and formulating the construct, developing dimensions and indicators of each variables, makes grating instruments, and arrange items statement in the form of enclosed questionnaire for organizational culture and managerial competence variables. Forperformance of lecturer variable arranged point of statement in observation sheet that comes with the observation guidelines.

\section{RESULT AND DISCUSSION}

From the calculation, It found that organizational culture has direct positive effect on the performance of lecturer. It can be concluded that the research hypothesis proposed that there is a direct positive effect organizational culture on performance of lecturers can be received and verified.

Results of testing the hypothesis that organizational culture directly affects on the performance of lecturer, with large path coefficient $=0.222$, so direct effect of organizational culture on performance of lecturer is 0.222 . The value of this coefficient implies an increase of one unit variable of organizational culture will improve performance of lecturer of 0.222 units, assumed other variables are constant.

The result is in line with research conducted by Dirwan, where the results of his research stated that organizational culture has direct impact significantly on the performance of lecturer at private university, the same research also conducted by Qomariah that there is a direct influence of organizational culture on performance of the lecturer at private college in the district of Jember. This finding is consistent with the opinion of Triguno, that color of work culture is the productivity in the form of behavior that can be measured, such as hard work, discipline, productive, responsibility, motivated, creative, innovative, responsive and independent. This means that the work culture is the foundation that will produce quality work process. Therefore, if the lecturers want to produce best quality work, they should have work with strong culture of work and the right work process.

Organizational culture is a common value system of what is believed and foremost on what and how something is done which produce norms and performance, expected to be completely formulated based on the agreement of each member of the organization, value systems that exist within the organization should be communicated well within an organization, as with the communication that can determine whether or not to successful organizations.

Lecturers as educators and teachers in obstetrics program at private university are expected always make changes in the activities of education and teaching, the change is meant changes to the learning activities of teaching does not simply pass on the education and teaching of each school year in the pattern or model of the same learning, because it this is certainly not in line with what is expected by university, especially those of private universities, where private universities where a greater emphasis on a more optimal result.

When lecturer is as one indicator that produce new human resources superior and intelligent, the lecturers demanded always make learning innovation, how the planning of learning, how the leaning material taught, how the teaching carried out in the classroom until finally the student as a potential human resource born as a humanresource that has a value of science and technology that is ready to compete in accordance with their respective competence.

Things that need to be considered by the lecturers for the purpose of education and teaching can be achieved in accordance with the expected results, namely to produce graduates of new human resources superior, smart, and competitive, so a lecturer in performing duties and expectations as educator and teaching must execute in detail and carefully by doing a good analysis, so the precision and accuracy of the final result from the execution of their duties can be realized well. Thus the hypothesis is verified.

From the calculation result, direct effect managerial competence on the performance of lecturer is expressed by Beta Model Number 2 is 0,156. It can be concluded that the research hypothesis proposed that there is a direct positive effect on the performance of the managerial competence of lecturers can be received and verified. Results of testing the hypothesis that the managerial competence directly affects the performance of the lecturer with a path coefficient $=0.156$. The value of this coefficient implies an increase of one unit managerial competencies will enhance the performance of lecturer at 0,156 units, by assuming other variables are constant.

This study is in line with the results of research conducted by Wirda and Azra, with research title "Managerial Competence And Its Effect on Performance of Creative Industries of West Sumatra. The results showed that there is the significant effect of the Managerial Competence on Performance of Creative Industries in West Sumatera. 
Lecturer with the duties and responsibilities that are often referred to as Tri Dharma of University, namely as educators and teachers, researchers, and community service, be a task that would be difficult for them to do if a leader become a leader they do not have an idea, ideas and thoughts good to make a planning, organizing, mobilization and supervision at colleges where they work, because it affects how the leadership of the organization particularly in view of higher education organizations can run well which of course when doing managerial leadership competencies.

Chairman or director inobstetrics program at private university is the leader in the organization, must has competence in formulating a program of work organization, that also be a reference and guide for all the lecturer in the organization to carry out the duties and responsibilities of each when they already know what the university leader want or planned, of course they will also participate and run a job that is in accordance with planning the organization.

Competence of the university leader in terms of identifying the problems associated with the work of lecturer, the ability to collect data and information, data and information process, how to formulate the factors internal and external that can inhibit and encourage managerial, choose alternative solutions up to take the right decision, set the duration of employment, and establish tools and methods for efficient achievement of organizational goals. This is the cornerstone of planning led private university of obstetrics study program that the lecturers in implementing the tasks of education and teaching, which started learning effectively and can master the learning material by aperseption, conveying competence to be achieved, adjust the material to the learning objectives, linking the material with knowledge relevant, accuracy discussion with learning materials, and systematically presents the material. It can happen in an effective learning if the leadership of the college is able to formulate a plan of organizational goals with their ability to collect data up to formulate and choose alternatives in taking the right decision in accordance with the objectives of the organization.

Applying the approach or strategy for effective learning and utilize resources and learning media in accordance with the competence to be achieved, by implementing the learning in accordance with the allocation of time planned be easily done by lecturers in teaching when the director or head of the private college of obstetrics in North Sumatra able to formulate and plan learning evaluation to measure the achievement of learning objectives by giving assignments corresponding basic tasks and functions of each faculty, with the atmosphere of effective communication, effective cooperation to foster harmony in the work, and the ability of the university leader to give orders educational work and teaching systematic.

Competence in compiling and evaluating the task of the lecturers and competence in delegating tasks according expertise with the regular system and harmonious cooperation work, will be able to form a behavior teaching faculty to demonstrate their skills in the use of learning resources, which generate messages and learning resources which are interesting. But of course assignments to lecturers must also conform to the standard formula size planning learning objectives have been decided by the leadership of the college, if this can be done by university leaders will certainly grow partisifasi active students through interaction of faculty and students, by responding to the participation of students with a positive response, with an open attitude to the response of these students, in which the involvement of students is so important, because they are told that they must show an open attitude toward student response, suggesting a personal relationship that is conducive to cultivate the joy and enthusiasm of the students in the study according to the lesson plan relevant and appropriate to the learning goals.

Tri Dharma of University implement education and teaching, research and community service are as tasks and responsibility of lecturers in university. In teaching, lecturers master learning materials, use of relevant learning materials, using the strategy or approach to learning appropriate to the material to be taught, maintaining student involvement in the classroom, by growing conduciveness and open communication in learning. This of course can be done when the chairman or director of a university leaders on Obstetrics Study Program able to put together an organization planning to make policies and decisions and to be able to empower the teachers to perform tasks well, research, education and teaching and community service in accordance with the field each lecturer. Additional capabilities are also to be understood and practiced by its leaders is the ability to coordinate the work, motivate lecturers to achieve the goal, create cooperation with professors, and set the standard of quality of work.

To formulate the right job in accordance with organizational objectives to be achieved, creating a standard measure, assess, to make decisions as the ability of the leaders of private universities of obstetrics study program, foster effective cooperation, coordinating the work of the faculty based on skills and tasks that are relevant, setting standards and measurement methods of work, assess the results of the work that has been achieved, decided recommendation on the work already accomplished, to formulate a job to repair if it has not fulfill the objectives drawn, making corrective actions and establish methods of work corrective action work. This capability becomes which is vital for leaders at private university in order to provide the results of the organization's work better and appropriate in the formulation of the work that had been developed for the achievement of the organization objectives seen from Tri Dharma of University implemented by lecturer 
properly, effectively, and efficiently, ie Tri Dharma of University: education and teaching, research and community service.

\section{CONCLUSION}

Based on the research that has been described previously, it can be concluded:

1. Organizational culture has positive direct effect on the performance of lecturerin obstetrics program at private university of North Sumatera. An organizational culture affect greatest in this study is an indicator of organizational culture on innovation and risk taking. In other words, the better the innovation and risk taking in the culture of the organization, the higher the performance of lecturerin obstetrics program at private university of North Sumatera.

2. Competence managerial has positive direct effect on the performance of lecturer in Obstetrics Program at private university of North Sumatera. Managerial competence affect greatest in this study is the managerial competence on monitoring indicators. In other words, the better oversight on managerial competence, the higher the performance of lecturer at private university of Obstetrics Study Program in North Sumatra.

\section{REFERENCEES}

[1] Alo, Liliweri. 2004. Dasar-dasar Komunikasi Antar Budaya. Yogyakarta : Pustaka Pelajar

[2] Amini. 2004. Perilaku Organisasi. Bandung: Citapustaka Media.

[3] Amstrong, Michael. Baron, A. 1998. Performance Manajemen. New York: The New Realities.

[4] Anas, Sudijono. 2001. Pengantar Statistik Pendidikan. Jakarta: Raja Grafindo Pers.

[5] Anoraga, Pandji. 1998. Psikologi kerja. Jakarta Rineka Cipta

[6] Anonim (2010). Pengembangan Kinerja Menuju Produktivitas (Telaah Masalah Sumber Daya Dosen PTS). http://jurnal-kopertis4.tripod.com/8-02.htm. 11 June 2010

[7] Anwar Prabu Mangkunegara. 2004. Manajemen Sumber Daya Manusia. Perusahaan cetakan pertama, penerbit PT. Remaja Rosdakarya. Bandung

[8] Ardhiana, Ratna. 2007. Pengaruh Budaya Organisasi dan Kepuasan Kerja terhadap Kinerja Karyawan pada PT. Telkom Kancateltuban. Jurnal Communication Science.

[9] Argyris, Chris. 1957. Personality and Organization, Herper. New York

[10] Arikunto, Suharsimi. 1990. Prosedur Penelitian : Suatu Pendekatan Praktek, Jakarta : Rineka Cipta.

[11] Arikunto, Suharsimi. 2005. Manajemen Penelitian. Jakarta: Renika Cipta.

[12] Arikunto, Suharsimi. 2006. Prosedur Penelitian. Jakarta: Renika Cipta.

[13] Armstrong. Michael and Baron, 1998. Performance Manajemen, (Alih Bahasa: Tony Setiarvan), Yogyakarta: Tugu Publisher.

[14] Arni Muhammad. 2000. Komunikasi Organisasi. Jakarta : Bumi Aksara.

[15] Benardin and Russel. 1993. Human Resources Management, An Experiential Approach, Mac Graw Hill, Book CO, Singapore

[16] Colquitt, A., Jason, LePine, A., Jeffery, and Wesson, J., Michael. 2009, Organizational Behavior, New York : Mcgraw-Hill Companies, Inc, 1221

[17] Daft, R.L. 1992. Organization Theory and Desain, $4^{\text {th }}$ edition. Singapore: West Publishing Company.

[18] Dirjen Dikti. 2010. Pedoman Beban Kerja Dosen dan Evaluasi Pelaksanaan Tridharma Perguruan Tinggi.Jakarta

[19] Ekosiswoyo, Rasdi., Rachman Maman. 2000. Manajemen Kelas. Semarang: IKIP Semarang Press.

[20] Hadjar, I. 1996. Dasar-Dasar Metodologi Penelitian Kuantitatif dalam Pendidikan. Jakarta: RadjaGrafindo

[21] Handoko, Hani. 1993. Penilaian Kinerja. Jakarta : Ghalia Indonesia

[22] Jalal, Fasli. 2009. Mengembangkan Dosen, Mahasiswa dan Sistem. Jakarta: Media Kampus.

[23] Jurnal Dinamika AkuntansiVol. 4, No. 2, September 2012, pp. 121-128 ISSN 2085-4277 http://journal.unnes.ac.id/nju/index.php/jda. Rini Maryuni Hariyati.

[24] Kamars, H.M.Dachnel. 2005. Administrasi Pendidikan : Teori dan Praktik. Padang : Universitas Putra Indonesia Press.

[25] Kaufman, Roger. 1988. Planning Educational Systems. New Holland Avenue : Technomic Publishing Company, Inc

[26] Katz, D \& Kahn, R.L. 1978. The Social Psychology of Organization. New York: Wiley.

[27] Kondalkar, V.G. 2007. Organizational Behaviour, New Age Internasional (P) Limited Publishers

[28] Luthans, Fred. 1998. Organizational Behaviour, New York: McGraw-Hill Book Co.

[29] Maslow, Abraham. 2003. Motivasi dan Kepribadian. Jakarta: Midas Surya Grafindo.

[30] Masri Singarimbun dan Sofian Effendi. 1982. Metode Penelitian Survei. Jakarta: Lembaga Penelitian, Pendidikan dan Penerangan Ekonomi dan Sosial. 
[31] Miller, Alex, dan Dess, Gregory, G. 1993. Strategic Management. McGraw Hill: Book.co.

[32] Prihatin Tiyanto PH. Jurnal Ekonomi dan Bisnis Vol. 365 No. 9, April 2010

[33] Pedhazur, Elazar, J. 1982. Multiple Regression in Behavioral Research. New York : CBS College Publishing.

[34] Riduwan. 2005. Belajar Mudah Penelitian Untuk Guru-Karyawan dan Peneliti Pemula.Bandung : Alfabeta.

[35] Riduwan. 2008. Cara Menggunakan dan Memaknai Analisis Jalur. Bandung: Alfabeta.

[36] Riduwan. 2009. Skala Pengukuran Variabel-Variabel Penelitian. Bandung: Alfabeta.

[37] Rivai,Veithzal dan Dedi, Mulyadi. 2005. Kepemimpinan dan Perilaku Organisasi. Jakarata: Raja Grafindo Persada.

[38] Robbins, Stephen P., 1991, Organizational Behavior 12th. New Jersey, Prentice Hall

[39] Robbins, Stephen P., 1996. Perilaku Organisasi-Konsep, Kontroversi, Aplikasi, Jakarta: Prenhallindo.

[40] Robbins, Stephen P., 1996. Organizational Behavior Concept, Controversies and Applications, $6^{\text {th }}$ edition, Englewood Cliffd. NJ: Prentice Hall Inc.

[41] Robbins, Stephen P., 2000. Organizational Behavior 9th edition. San Diego State University. Prentice Hall International , Inc

[42] Robbins, Stephen P., 2002. Perilaku Organisasi. Versi Bahasa Indonesia. Jakarta: Prenhallindo.

[43] Robbins, Stephen P., 2003. Organization Behavior, 9th edition. (Perilaku Organisasi, edisi ke 9), edisi Indonesia. Alih Bahasa Tim INDEKS, Jakarta: INDEKS Kelompok GRAMEDIA.

[44] Robbins, Stephen P., 2008. Perilaku Organisasi. Jakarta: Salemba Empat.

[45] Roberts, Artur D. 1992. Organizational behavior concepts. New York: Printice Hall.

[46] Ruky, Ahmad S. 2002. Sistem Manajemen Kinerja . PT Gramedia Pustaka Utama. Jakarta

[47] Sagala, Saiful. (2006). Konsep dan Makna Pembelajaran. Bandung: CV. Alfabeta.

[48] Schein, E.H. 2004. Organizational culture and leadership second edition Jossey Bass Publishers San Fransisco.

[49] Slameto. 2010. Belajar dan Faktor-Faktor yang Mempengaruhinya. Jakarta : Rineka Cipta. Sobur, Alex

[50] Slocum, Hellriegel. 2009. Principles of Organizational Behavior. South-Western: Cengage Learning.

[51] Stoner, A.F. James. DKK. 2000. Manajemen, Edisi Bahasa Indonesia. Jakarta : PT. Prenhallindo

[52] Spencer, Peter M. \& Signe M. Spencer. 1993. Competence at Work "Model for Superior Performane". New York: John Wiley \& Sons Inc.

[53] Sudar. Pengaruh Kemampuan Manajerial Dan Kualitas Sdm Aparat Pemerintahan Desa Terhadap Pembangunan Desa. Jurnal Ilmiah Mahasiswa Pascasarjana Manajemen Volume II | Nomor 3 | September 2013

[54] Sudjana, 1989. Metode Statistika.Bandung : Tarsito.

[55] Sudjana, Regresi dan Korelasi. Bandung : Tarsito

[56] Sugiyono. 2006. Metode Penelitian Pendidikan. Bandung: Alfabeta.

[57] Sugiyono. 2008. Metode Penelitian Pendidikan, Pendekatan Kuantitatif, Kualitatif, dan R\&D. Bandung: ALFABETA

[58] Undang-Undang Nomor 14 Tahun 2005. Tentang Guru dan Dosen, 2006, Jakarta: Sinar Grafika.

[59] Universitas Muslim Nusantara Al - Wasliyah. 2010. Visi \& Misi Perguruan Tinggi. (online) http://www.umnaw.com/visimisi.htm

[60] Usman, Moch. Uzer. 2009. Menjadi Guru Profesional. Bandung : Remaja Rosdakarya.

[61] Vecchio, P., Robert. 1995. Organizational Behaviour. Orlando: The Dryden Press

[62] Wayne, Pace, R. dan Don F. Faules. 2005. Komunikasi Organisasi, Strategi Meningkatkan Kinerja Perusahaan. Editor: Dedy Mulyana. PT. Remaja Rosdakarya. Bandung.

[63] Wexley, K.N dan Yukl, G.A. 1977. Organizational behavior and personal psychology. Homewood, Illinois: Richard D. Irwin

[64] Wibowo. 2007. Manajemen Kinerja. Jakarta: Rajawali Pers.

[65] Wibowo. 2009. Manajemen Kinerja. Jakarta: Rajawali Pers.

[66] Widjaja, Aw. 1993. Komunikasi dan Hubungan Masyarakat. Jakarta : Bumi Aksara. Hlm. 34

[67] Winardi. J. 2007. Manajemen Perilaku Organisasi. Jakarta: Kencana Prenada Media Group.

[68] Yukl, Gary. 2009. Kepemimpinan dalam Organisasi. Edisi Indonesia. Jakarta: Indeks.

[69] Zweel, Michael. 2000. Creating a Culture of Competence. New York: John Wiley \& Sons Inc. 